\title{
Soil-landscape relationship as indicated by pedogenesis data on selected soils from Southwestern, Iran
}

\author{
Hamidreza Owliaie a,*, Mahdi Najafi Ghiri b, Sirous Shakeri c \\ a Department of Soil Science, College of Agriculture, Yasouj University, Yasouj, Iran \\ ${ }^{\mathrm{b}}$ College of Agriculture and Natural Resources, Darab University, Darab, Iran \\ c Department of Agriculture, Payame Noor University, Tehran, Iran
}

\section{Article Info}

Received : 02.10 .2017

Accepted : 02.01.2018

\begin{abstract}
Soils of semiarid regions of Dehdasht and Choram in Southwestern Iran have formed on alluvium derived from mixed calcareous-gypsiferous materials from Lower Miocene to Upper Pliocene. In order to characterize and classify the soils and to determine the soillandscape relationship in the area, nine pedons located on different physiographic positions including plateau, river alluvial plain, piedmont plain, alluvial plain and alluvial fan have been described, sampled and analyzed. Physicochemical analyses, clay mineralogy and micromorphological studies were performed. The results showed that topography and parent material were two important soil forming factors affecting soil formation in the area. The soils were dominated by carbonate, gypsum, and clay illuviation and accumulation. More developed soils were found on the stable plateau and piedmont plain. Clay illuviation and argillic horizon development in soils of the more stable alluvial plain were assumed to be relict features from presumably more humid climates. Palygorskite, illite, chlorite, smectite, kaolinite, and quartz clay minerals were identified in almost all physiographic surfaces, but more palygorskite and less smectite were found in the soils with gypsiferous parent materials. Observations by SEM revealed the occurrence of neoformed palygorskite as thread-like faces and coating of gypsum crystals and marly matrix. Coating and infilling of gypsum and calcite crystals in voids and channels were common pedofeatures observed in the soils studied. Two different distribution patterns of Fe-Mn oxides were identified in aquic and non-aquic soils.
\end{abstract}

Keywords: Clay mineralogy, gypsum, soil landscape, soil micromorphology.

(c) 2018 Federation of Eurasian Soil Science Societies. All rights reserved

\section{Introduction}

There have been many attempts to correlate soil properties with various factors, such as parent material and topography (McBratney et al., 2000). Soil geomorphology is an assessment of the genetic relationships between soils and landforms (Gerrard, 1992). Birkeland (1999) defined soil geomorphology as the study of soils and their use in evaluating landform evolution, age and stability, surface processes and paleoclimates.

The differences in soil properties with landscape position are usually attributed to differences in runoff, erosion, and deposition processes, which affect soil genesis and vegetation development (Dahlgren et al., 1997; Lark, 1999). Moazallahi and Farpoor (2011) found the landscape as a significant soil forming factor causing different physicochemical and clay mineralogical properties in soils of southern Iran. Khresat and Qudah (2006) found that carbonate, clay elluviation-illuviation, and salt accumulation are the dominant pedogenic processes in the arid soils of northeastern Jordan.

Sanjari et al. (2011) investigated paleosols with argillic horizons on stable pediment surfaces in Jiroft area, central Iran. They found that secondary gypsum and calcite were accumulated in mantled pediments, but

\footnotetext{
${ }^{*}$ Corresponding author.

Department of Soil Science, College of Agriculture, Yasouj University, Yasouj, 75918-74831 Iran

Tel.: +987431006112
}

e-ISSN: 2147-4249

E-mail address: owliaie@gmail.com DOI: $10.18393 /$ ejss.376284 
moving down the slope toward lowlands, salts-more soluble than gypsum-have been accumulated. Nooraie (2010) in the study performed in Loot Desert, reported a close relationship between geomorphic position and soil genesis and evolution. He pointed out that undeveloped Entisols were formed on young unstable pediment surfaces. On the other hand, salic, gypsic, petrosalic, and petrogypsic horizons were formed on developed soils of playa landform.

Study of clay minerals and their alteration provides important information on the pedogenic history of soils as well as soil genesis and evolution (Wilson, 1999). Clay mineralogy in soil studies helps in better conception of soil genesis and development (Moore and Reynolds, 1997). Soil clay minerals have two main sources: (1) neoformation and transformation by pedogenic processes, and (2) inheritance from parent rocks, or addition by eolian or fluvial processes to soil surface (Schaetzl and Anderson, 2005).

Palygorskite, smectite, chlorite, illite, kaolinite, and vermiculite have been reported as dominant clay minerals in arid and semi-arid areas of Iran (Salehi et al., 2002; Khormali and Abtahi, 2003; Owliaie et al., 2006; Nadimi and Farpoor, 2013; Sarmast et al., 2016; Sarmast et al., 2017). Neoformation of palygorskite as a result of calcite and gypsum precipitation seems to be a major pathway for the occurrence of this mineral in the studied soils of southwestern Iran. Moreover, large amounts of smectite seem to be inherited from the Miocene marl formations (Owliaie et al., 2006). A close relationship between geomorphic positions and palygorskite morphology and its origin was reported by Farpoor et al. (2002) in Rafsanjan area in the southcentral part of Iran.

High amounts of gypsum are frequently found in soils of arid and semi-arid environments. Many macro and micro forms of soil gypsum have been reported in the literature. Owliaie et al. (2006) reported prismatic, lenticular, platy, tabular, pseudo-hexagonal, and hexagonal as well as interlocked plates of gypsum in relation to stage of soil development of the studied soils of southwestern part of Iran. They found a clear relationship between the size of pore space in soil matrix and dimensions of lenticular crystals.

Hashemi et al. (2011) reported that soil moisture, texture, and landscape position play an important role in the formation of pedogenic gypsum. They stated that well-crystallized gypsum was observed in soils with the lighter texture. The shape, size, and position of gypsum crystals, within the soil matrix, were used to determine their source (Buck and Van Hoesen, 2002; Carter and Inskeep, 1988).

Calcite is one of the best studied, but also one of the most flexible pedogenic minerals. It shows a wide variety of shapes and habits, and occurs as well in arid and semiarid soils with restrained drainage (Stoops and Delvigne, 1990). The occurrence of calcitic pedofeatures in calcareous soils of southern and southwestern Iran has often been reported in the literature (Khormali et al, 2006; Owliaie et al., 2006; Owliaie, 2012). According to Wright (1987), the type of pedogenic calcium carbonate is controlled mainly by the parent material, climate, and vegetation.

Iron and manganese oxides as well as hydroxide minerals are very active constituents in soils because they are sensitive to environmental changes and they move frequently along soil cracks or holes and deposit in peds (McKenzie 1989; Dixon and Skinner, 1992). In soils, the reduction and oxidation of iron and manganese, as a result of seasonal changes in soil moisture, contributes to the formation of cutans, forming coatings and concretions (Zhang and Karathanasis, 1997; Liu et al., 2002). Owliaie (2014) reported two different distribution patterns of Fe-Mn oxides in aquic and non-aquic soils due to more mobility of these oxides in aquic conditions.

The Dehdasht and Choram Plains in the center of Kohgilouye Province have relatively large diversity in terms of topography, soil types, and geological formations that have made this an appropriate area to study the relationship between these factors. Limited data are available for the pedogenesis of this area; therefore, the aims of the present research were to study 1) the physicochemical and morphological soil properties, and micromorphology of the soils related to physiographic positions, 2) the soil genesis and classification using both Soil Taxonomy and World Reference Base (WRB) Systems, and 3) the mineralogy of clay fraction in the studied soils.

\section{Material and Methods}

\section{Study area}

Dehdasht and Choram Plains are located in the central part of Kohgilouye Province, Southwestern Iran (Figure 1). Mean elevation of Dehdasht and Choram Plains are 790 and $735 \mathrm{~m}$ above sea level (a.s.l.), respectively. Two seasonal rivers which pass through the plain, have distinctive effects on transportation and sedimentation of materials (Figure 2). 


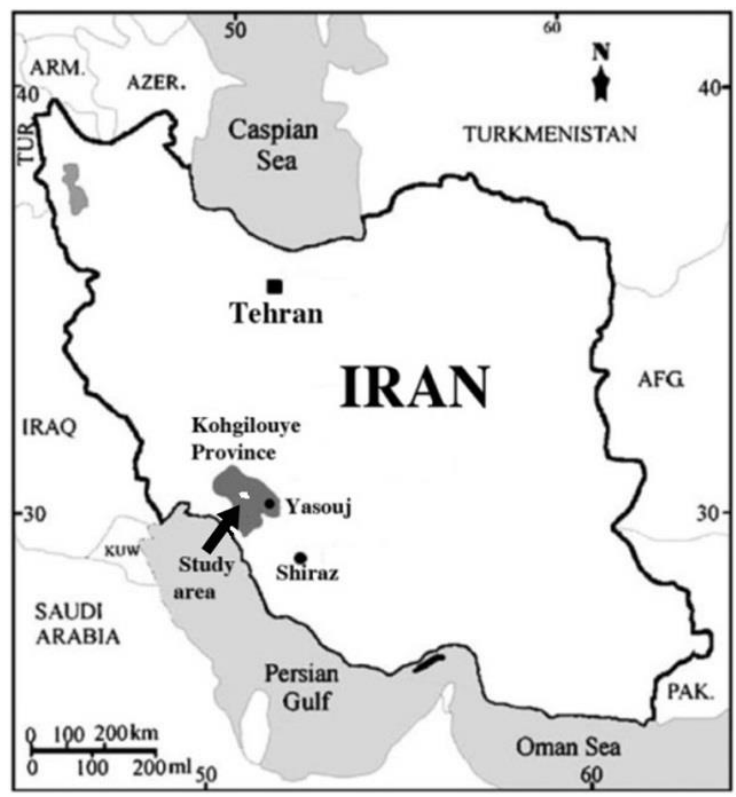

Figure 1. Location of Kohgilouye Province, southwestern Iran and the study area

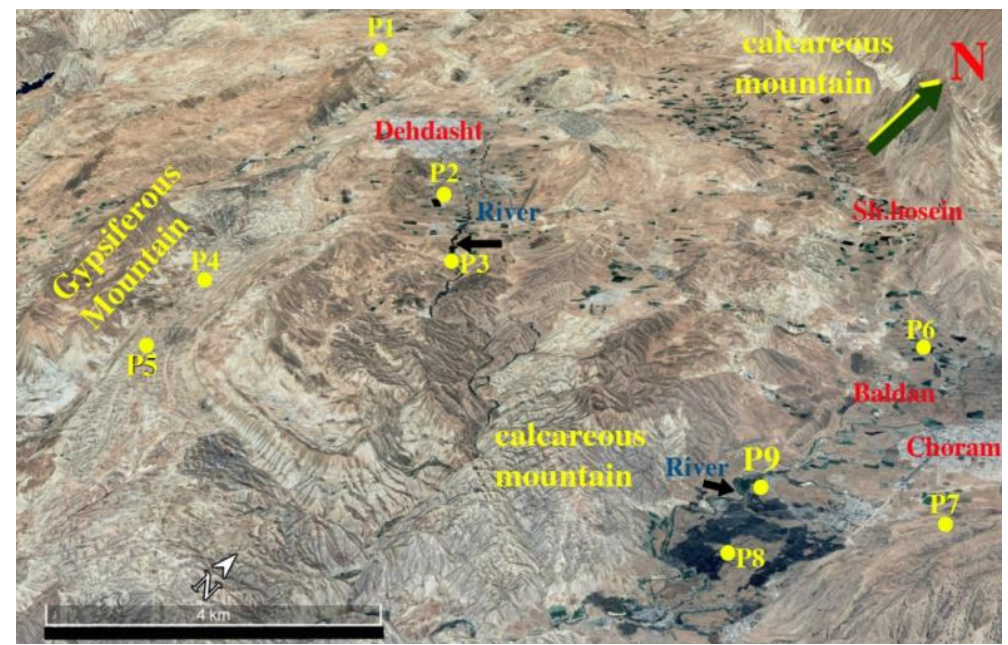

Figure 2. Map of the study area indicating topographic positions and representative pedons.

This region is part of the Zagros orogenic zone, which extends throughout the province. As indicated in Figure 3, four main geological units are recognized in the area. The Bakhtiari Formation, exposed in the east and southeast Mountains, consist of sandstone, limestone, conglomerate and gray marl (Upper Pliocene). The Gachsaran Formation (Lower Miocene) is composed of thick bedded alternating layers of anhydrite and marls (exposed in the east and south of the region) (Figures 2, 3). The Mishan Formation (Lower to Middle Miocene) consists of gray marls with ferruginous materials at its base (exposed parallel to Gachsaran Formation). The Aghajari Formation (Upper Miocene to Pliocene) consists of red sandstone, pebbly sandstone and silty marls with gypsum interlayer (exposed in central and northeast of the region. Overlying the Aghajari Formation are Quaternary alluvium and recent deposits (Geological Survey of Iran, 1995).

The soil moisture regime of the study area is ustic, and the temperature regime is hyperthermic (Banaei 1998). Climatic data indicates a mean annual rainfall of $478 \mathrm{~mm}$, and a mean annual temperature of $21.5^{\circ} \mathrm{C}$ (for a 25-year recording period at Dehdasht weather station).

\section{Soil transect and field characterization}

Different landforms in the area were identified using Google Earth and topographical maps, together with detailed field work. Piedmont plain, alluvial fan, alluvial plain, river alluvial plain, and plateau were dominant physiographic units recognized in the area studied (Figure 2). 


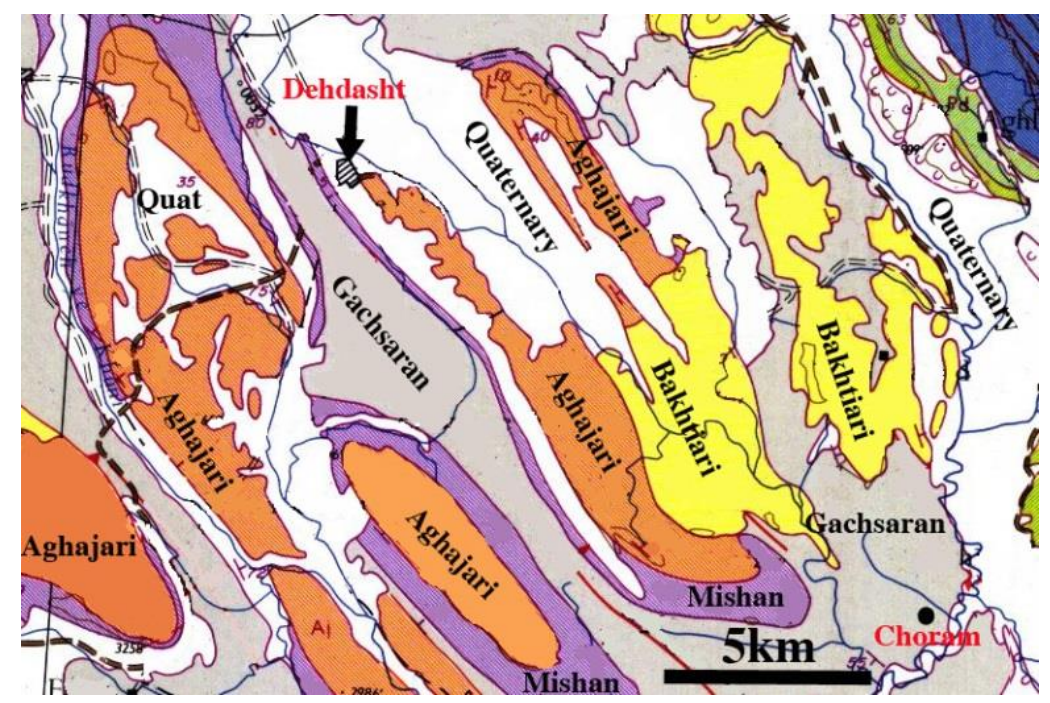

Figure 3. Regional geological map of the study area

Nine representative pedons on different physiographic units were sampled and studied, (Figure 2). Pedon 1 on plateau, pedons 2, 4, 6 and 8 on the piedmont plain, pedons 3 and 9 on the river alluvial plain, and pedons 5 and 7 on the alluvial fan were studied. Soil pedons were classified according to Taxonomy (Soil Survey Staff, 2014) and WRB (FAO, 2015) systems.

Air-dried soil samples were sieved through a $2 \mathrm{~mm}$ sieve and routine soil physical and chemical properties were investigated. Organic carbon was measured by wet oxidation with chromic acid and back titration with ferrous ammonium (Jackson, 1975). Calcium carbonate equivalent (CCE) was measured by acid neutralization and gypsum was determined by precipitation with acetone (Salinity Laboratory Staff, 1954). Cation exchange capacity (CEC) was determined using sodium acetate ( $\mathrm{NaOAc}$ ) at a pH of 8.2 (Chapman, 1965). Soil pH was measured with a glass electrode in a saturated paste and electrical conductivity (EC) was determined in the saturation extract (Salinity Laboratory Staff, 1954). Soil texture was determined using the pipette method (Day, 1965).

Fifteen soil samples were selected for clay mineralogical analysis. Calcium carbonate, organic matter, and iron oxides were removed and clay fraction was separated (Jackson, 1975; Kittric and Hope, 1963). Four slides including Mg saturated, Mg saturated and treated by ethylene glycol, K saturated, and K saturated and heated to $550{ }^{\circ} \mathrm{C}$ were analyzed using a Philips D500 diffractometer, using Ni-filtered Cuk $\alpha$ radiation $(40 \mathrm{kV}$, $30 \mathrm{~mA}$ ). Four major geological strata were sampled for mineralogical studies. The semi-quantitative contents of the clay minerals were estimated according to Johns et al. (1954). Semi-quantitative assessments make the identification of individual components in polymineralic samples much more valuable. Small soil clods were mounted on aluminum stubs and coated with gold for scanning electron microscopy (SEM) observation using a Cambridge SEM.

Thin sections were prepared using the methods described by Murphy (1986). Undisturbed soil samples were impregnated under vacuum with an acetone-diluted polyester resin (60/40 ratio). Oriented sections were cut with a diamond saw and cemented onto glass microscope slides. They were ground and polished to a thickness of about 20-30 $\mu \mathrm{m}$. Micromorphological descriptions were made according to Stoops (2003) using a Zeiss petrographic microscope.

\section{Results and Discussion}

\section{Physicochemical properties}

Table 1 shows the physicochemical properties of the studied pedons. All the soils are calcareous or gypsiferous throughout the profile. Calcium carbonate equivalent (CCE) varied between 38.1 and $86.3 \%$. An increasing trend of calcium carbonate with depth was recorded in most of the pedons studied. Electrical conductivity of saturation extracts (ECe) was between 0.2 and $2.3 \mathrm{dSm}^{-1}$. More EC contents were measured in gypsic horizons. The soils exhibited a narrow range of $\mathrm{pH}$ (7.4 to 8.2) within their solums. Clay content was measured to be between 20 and 55\% and gypsum content to be between trace amounts and $8.6 \%$. The organic carbon content is generally low to moderate, varied between 0.12 and $4.84 \%$. The most content of OC was measured in mollic epipedon of pedon 8. The low organic matter content of the studied soils 
contributed to land degradation. CEC varied between 6.3 to $36.8 \mathrm{cmol}_{(+)} \mathrm{kg}^{-1}$. More CEC was measured in the soils of physiographic surfaces of piedmont plains and plateau with more clay content.

The studied soils were classified as Entisols, Inceptisols, Alfisols, and Mollisols with calcic, gypsic, cambic, and argillic horizons and ochric and mollic epipedons based on Soil Taxonomy (Soil Survey Staff, 2014) and Calsisols, Cambisols, Regosols, Gypsisols, Luvisols, and Kastanozems based on WRB (FAO, 2015).

Table 1. Physicochemical properties of representative pedons

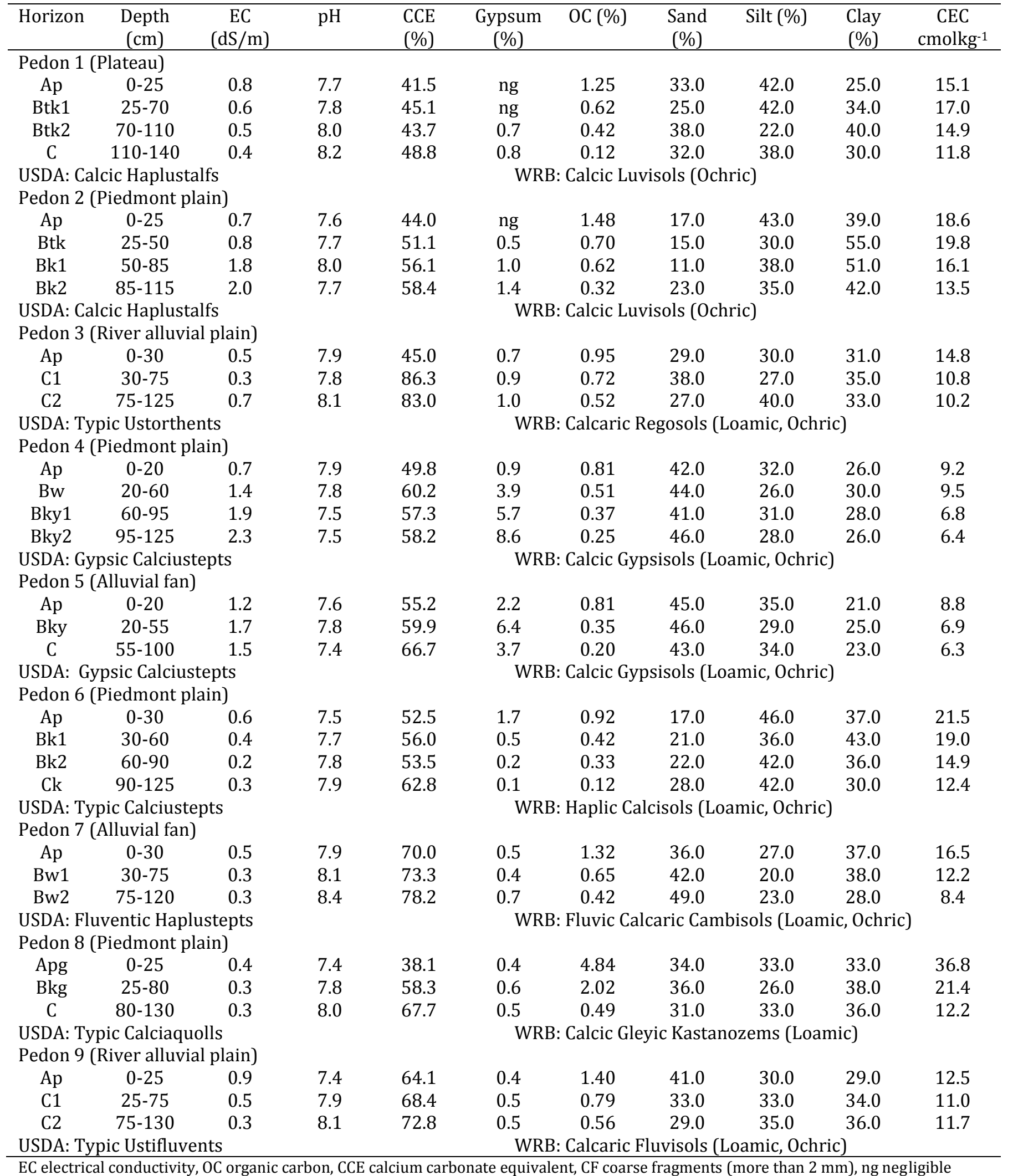


The soils formed adjacent to Gachsaran Formation (pedons 4 and 5), in the west of the study area, have a mixture of gypsiferous and calcareous parent materials. The formation of secondary gypsum and calcite is the dominant pedogenic process in these soils. The depth of calcic and gypsic horizons in these soils was highly related to the amount of precipitation and physiographic position. These pedons were classified as Gypsic Calciustepts. Pedon 8 in Choram region (piedmont plain) is a paddy soil with a locally aquic soil moisture regime and a mollic epipedon at surface and a calcic horizon at subsurface. This pedon was classified as Typic Calciquolls (Table 1).

Undeveloped Entisols (pedons 3 and 9) were formed on young unstable river alluvial plain with seasonal sedimentation by Dehdasht and Choram Rivers, respectively. These pedons were classified as Typic Ustorthents and Typic Ustifluvents, respectively. The northern sector of the region shows stable physiographic units of plateau and piedmont plain. The most evolved soil pedons were described in this sector (Calcic Haplustalfs).

Clay content increased with depth in most of the pedons, indicating illuviation of clay. The presence of argillic horizons in the more stable positions of plateau and piedmont plain (Pedons 1 and 2) in a semi-arid region, indicated a more humid paleoclimate in the history of the area. Micromorphological observations support these findings (Figure 6e). No argillic horizon was found in the other unstable positions. It seems that the stability of the geomorphic surface has been an important factor affecting the formation/preservation of argillic horizon through time. Besides, the formation of argillic horizons in arid soils of Central Iran was attributed to a more humid paleoclimate reported by Nadimi and Farpoor (2013).

The size, shape, and position of gypsum crystals, within the soil matrix, have been used to determine their origin (Buck and Van Hoesen, 2002). It has been suggested that diversity of crystal morphology results from changing micro-environmental conditions in soils through time (Amit and Yaalon, 1996). SEM observations of the present study showed that pedogenic gypsum crystals can occur individually or in clusters (nodules and plugs) within the soil groundmass and pores (Figures 5e and 5f). Amit and Yaalon (1996) identified four different crystal forms of gypsum included lenticular, prismatic, alabastrine microcrystalline, and fibrous crystals in relation to stage of soil development.

\section{Clay minerals \\ Rocks}

Chlorite, illite, smectite, palygorskite, quartz, and interstratified minerals are the major clay minerals within the rock samples studied (Table 2). Smectite was dominant in the younger sediments (Bakhtiari and Aghajari formations), in comparison with the older sediments (Mishan and Gachsaran formations) in which palygorskite was most abundant. The inverse correlation between smectite and palygorskite supports the hypothesis of the conversion of these two minerals to each other. Only small amounts of palygorskite were observed in the youngest formation. The association of smectite and palygorskite in the Oligo-Miocene limestone and marl is consistent with the results of the others (Pletsch et al., 1996; Khormali and Abtahi, 2003). Moderate to large quantities of illite and chlorite were found in all formations. Khademi and Mermut (1998) found palygorskite and sepiolite and appreciable amounts of mica and smectite in the clay fraction of the Oligo-Miocene limestone of central Iran. All formations contained small quantities of interstratified minerals, but only the youngest contained measurable amounts of quartz.

Table 2. Relative abundance of different clay minerals in the clay fraction of the carbonate-free residues of the rock samples studied ${ }^{\mathrm{a}}$

\begin{tabular}{cccccccc}
\hline Rock & Age & Ch. & Il. & Sm. & Pa. & Qr. & Is. \\
\hline R1 & Lower Miocene & ++ & +++ & + & +++ & + & + \\
R2 & Lower to Middle Miocene & +++ & ++ & ++ & ++ &.+ & + \\
R3 & Upper Miocene to Pliocene & ++ & ++ & +++ & + & + & + \\
R4 & Upper Pliocene & ++ & ++ & +++ & + & ++ & + \\
\hline
\end{tabular}

+ : Relative abundance of minerals, tr=trace. ${ }^{a}$ Ch, chlorite; Il, illite; Sm, smectite; Pa, palygorskite; Qr, quartz; Ve, vermiculite; Is, Interstratified minerals. R1=Gachsaran, R2=Mishan, R3=Aghajari, R4=Bakhtiari.

\section{Soils}

Palygorskite, chlorite, illite, smectite, vermiculite, kaolinite, quartz and interstratified minerals are the major clay minerals within the soils (Table 3). The presence of moderate to high contents of illite and chlorite in the soils can be related to inheritance from parent rocks. Larger contents of these minerals in parent rocks or sediments support this hypothesis. High leaching together with low $\mathrm{pH}$ and removal of interlayer hydroxides were reported as the ideal conditions for chlorite formation in soils (Branhisel and Berstesch, 
1992). That is why the arid moisture regime of the present research is not favorable for the pedogenic formation of chlorite. Thus, chlorite in soils of the study area is inherited (Owliaie et al., 2006).

However, there is some indication that mica may form pedogenically in arid soils as well, but only in special conditions, mainly through K fixation of pre-existing smectite (Mahjoory, 1975; Sanguesa et al., 2000). Simple transformation of illite to smectite may play a major role in decreasing illite content at soil surface (i.e. pedons 1, 2, 6 and 8). Climatic condition in the study area can provide a leaching environment for the release of $\mathrm{K}^{+}$from illite. Moreover, the soil environment, high in $\mathrm{Mg}$ and Si mobility, may create favorable condition for the formation of smectite through transformation at the soil surface (Owliaie et al., 2006).

Table 3. Relative abundance of clay minerals a $(<2 \mu \mathrm{m})$

\begin{tabular}{|c|c|c|c|c|c|c|c|c|}
\hline Pedon/horizon & Ch. & Il. & Sm. & $\mathrm{Pa}$. & Ka. & Ve. & Qr. & Is. \\
\hline $1 / \mathrm{Ap}$ & ++ & + & +++ & + & + & + & tr. & tr. \\
\hline 1/Btk2 & +++ & ++ & ++ & ++ & tr. & + & + & + \\
\hline $2 / \mathrm{Ap}$ & ++ & + & +++ & ++ & + & tr. & $\operatorname{tr}$ & + \\
\hline 2/Btk & ++ & +++ & + & ++ & tr. & tr. & + & + \\
\hline 2/Bk2 & ++ & +++ & + & ++ & + & $\operatorname{tr}$ & ++ & + \\
\hline 4/Ap & ++ & + & ++ & ++ & + & tr. & + & tr. \\
\hline 4/Bky1 & ++ & + & + & ++++ & + & tr. & + & tr. \\
\hline $5 / \mathrm{Ap}$ & + & ++ & ++ & ++ & + & + & + & tr. \\
\hline 5/Bky & ++ & ++ & + & ++++ & + & tr. & + & + \\
\hline 6/Ap & ++ & + & +++ & + & tr. & + & tr. & tr. \\
\hline 6/Bk2 & +++ & ++ & + & ++ & tr. & tr. & + & + \\
\hline 8/Apg & + & + & ++++ & + & tr. & tr. & + & + \\
\hline 8/Bkg & ++ & ++ & +++ & tr. & + & + & tr. & tr. \\
\hline 9/Ap & + & + & +++ & tr. & + & + & + & tr. \\
\hline $9 / \mathrm{C} 2$ & ++ & ++ & + & ++ & + & tr. & + & tr. \\
\hline
\end{tabular}

+ : Relative abundance of minerals, $\operatorname{tr}=$ trace.

aCh, chlorite; Il, illite; Sm, smectite; Pa, palygorskite; Ka, kaolinite; Qr, quartz; Ve, vermiculite; Is, Interstratified minerals.

Maximum content of smectite is noticed in pedon 8 with aquic soil moisture regime (Table 3 and Figure 4d). The presence of large amounts of this mineral in poorly soils is reported by Abtahi and Khormali (2001) and Aoudjit et al. (1995). They discussed there are three main sources of smectite in soils: (1) neoformation from soil solution, (2) detrital origin or inheritance, (3) transformation of other clay minerals. Low-lying topography, poor drainage and base-rich parent material, favorable chemical conditions characterized by high $\mathrm{pH}$, high silica activity and an abundance of basic cations are the factors strongly influenced the origin and distribution of smectite in soils.

Some part of the smectite is inherited from highly smectite marl formations, but the distinction between inherited and newly-formed clay minerals is difficult to discern. Some part of the smectite is inherited from highly smectite marl formations, although some may be the product of palygorskite weathering and transformation of illite particularly at the surface horizons.

A broad smectite peak (Figures $4 \mathrm{a}$ and $4 \mathrm{~b}$ ) after ethylene glycol treatment of some horizons (i.e. Btk2 horizon of pedon 4 and Ap horizon of pedon 2) appeared indicating the presence of high charge and/or low crystalline smectite in the soil, which suggests the inheritance origin of this mineral in the studied soils. In contrast, a sharp smectite peak in aquic soil (pedon 8), suggests a pedogenic origin of this mineral (Figure $4 d)$. Smectites with lower layer charge are present in the soils having a longer effective time of pedogenesis, suggesting alteration of the high-charge smectites with time (Gillot et al., 2001). Rezapour et al. (2012) and Rezapour (2014) reported low crystalline smectite in the cultivated soils of northwestern of Iran, suggested a neoformed clay mineral.

Trace to very low contents of vermiculite is observed in surface horizons of the soils studied. The occurrence and stability of vermiculite in calcareous and silica-rich soils have not been well-documented (Boettinger and Southard, 1995). According to Wilson (1999) with regard to the transformation of clay minerals, a general example would be: illite $\rightarrow$ vermicullite $\rightarrow$ smectite.

At about $\mathrm{pH}>6$ (as in case of the studied soils), Al is not soluble. In contrast, Si is highly soluble especially in the common $\mathrm{pH}$ of around 8 (as in calcareous soils of southern Iran). Therefore, high Mg present in calcareous materials can substitute $\mathrm{Al}$ in the lattice and form smectite. However, vermiculite is not stable and there is no evidence showing the existence of this mineral in the studied soils. Alteration of mica is the main pathway for the occurrence of pedogenic vermiculite in the soils (Churchman and Lowe, 2012). 

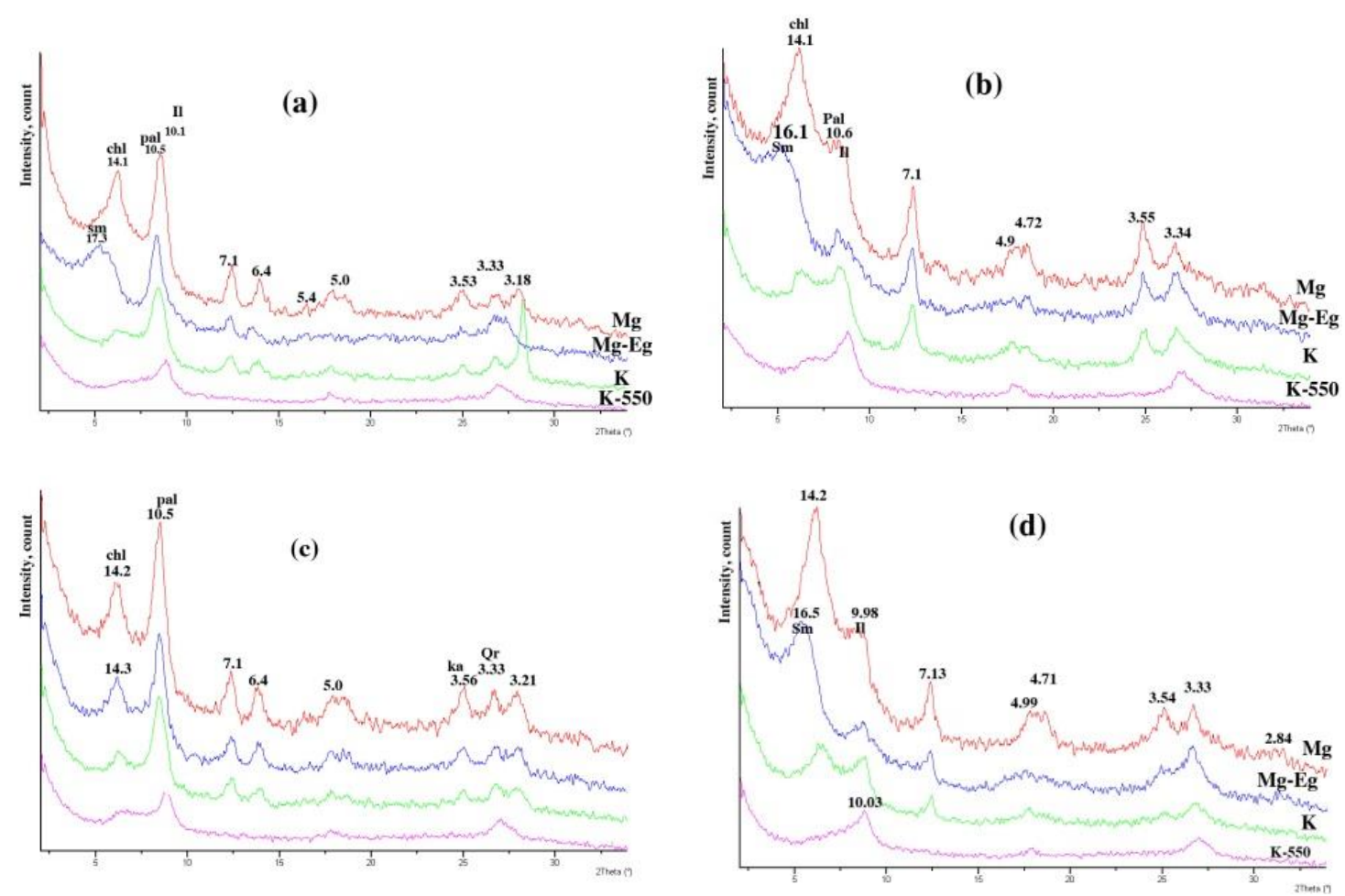

Figure 4. X-Ray diffractograms of the clay fraction, a) Btk2 horizon of pedon 1, b) Ap horizon of pedon 2, c) Bky1 horizon of pedon 4, d) Apg horizon of pedon 8, Sm: Smectite, I: Illite, Pa: Palygorskite, Ch: Chlorite, Ka: Kaolinite. Mg=Mg saturated; $\mathrm{Mg}-\mathrm{Eg}=\mathrm{Mg}$ saturated with Ethylene glycol; $\mathrm{K}=\mathrm{K}$ saturated; $\mathrm{K}-550=\mathrm{K}$ saturated and heated to $550{ }^{\circ} \mathrm{C}$.

The results of the current research indicate that inheritance origin due to a moderate to large amount of smectite in parent rocks especially in younger formations and transformation from palygorskite are the main pathways for the occurrence of smectite in the soils studied (except for the pedon 8 with aquic condition). Illite is a main precursor mineral for the formation of smectite in soils, particularly at the surface horizons. Palygorskite is another possible precursor mineral for smectite formation in similar environments. The results indicate that there is a reverse correlation between smectite and palygorskite in the studied pedons. The maximum of palygorskite is observed in deeper horizons. It can indicate that palygorskite, weathers and transforms to smectite at soil surface. Similar results are reported in literature (Abtahi, 1980; Khademi and Mermut, 1998; Owliaie et al., 2006).

Increase of $\mathrm{Mg} / \mathrm{Ca}$ ratio after gypsum crystallization in Tertiary followed by Miocene orogenic activities in arid lands of Iran was reported in the literature (Khademi and Mermut, 1998; Owliaie et al., 2006; Moazallahi and Farpoor, 2009). Farpoor et al. (2002) have reported a close relationship between geomorphic positions and palygorskite morphology and origin in the soils of Rafsanjan area in the south central part of Iran. A close relationship between palygorskite morphology and depth of soil was observed on different landforms in the soils of southwestern Iran (Owliaie et al., 2006).

Traces to minor contents of quartz and interstratified minerals are observed in clay fraction of the studied soils (Table 3). More contents of these minerals are found in clay fraction of the deeper horizon with lower weathering suggesting a lithogenic origin for these minerals.

According to the results (Tables 2 and 3), the relative amount of palygorskite in soils is much more than the parent rock samples (especially in gypsiferous soils). It may suggest that the pedogenic origin for palygorskite formation is more important than lithogenic. It has been stated that palygorskite in soils of arid and semi-arid environment has two main origins: (1) inheritance from parent materials and (2) pedogenic formation (Badraoui et al., 1992; Monger and Daugherty, 1991). Pedogenic palygorskite has been proposed to form by alteration of precursor minerals such as smectite or by precipitation from solution (Singer, 1984). Neoformation of palygorskite seems to need large activities of Si and Mg with a pH of about 8 (Singer, 1989). Figure 5d shows SEM micrographs of palygorskite fibers on gypsum crystals (Bky1 horizon of pedon 4).

A high amount of palygorskite was observed in gypsiferous pedons (pedons 4 and 5) compared with calcareous pedons (Table 3). Owliaie et al. (2006) concluded that calcareous and gypsiferous soils can provide buffered alkaline media with essential anions and cations for pedogenic formation of palygorskite but properties of the gypsiferous soils may result in a more favorable medium for this purpose. 
Presence of first $(7.1 \AA$ ) and second (3.57 $\mathrm{A}$ ) order peaks of kaolinite prove the formation of this clay mineral in the soils studied (Dixon and Weed, 1989). Warm and humid climate with good drainage was reported for kaolinite formation (Nadimi and Farpoor, 2013; Khormali and Abtahi, 2003). Since such an environment could not be found in the area at present, kaolinite should have been inherited in the studied soils. Besides, the role of kaolinite-bearing eolian deposits in the arid environment of the present research should not be neglected as a probable source of this mineral.

Abbaslou et al. (2013) in a study in arid regions of Hormozgan Province, southern Iran, concluded that the soil mineralogy did not vary systematically with depth but showed spatial variations, and the relative influence of mineral distribution in topsoils was mainly affected by parent rocks and the geomorphological setting.

\section{Micromorphology}

Table 4 shows a brief description of some micromorphological properties of thin sections from selected soils. The overall microstructure of the studied soils ranged between weakly and well separated subangular blocky. The $\mathrm{c} / \mathrm{f} 10 \mu \mathrm{m}$ related distribution is porphyric and ranged from $2 / 8$ in the Bkg horizon of pedon 8 to $6 / 4$ in the Bky2 horizon of pedon 4. Reddish brown groundmass dominated in the soils with gypsiferous parent material (particularly pedons 4 and 5), whereas yellowish brown to bright brown groundmass prevailed in the soils with calcareous parent materials. Since soils are highly calcareous or gypsiferous, the b-fabric is mostly crystallitic (Figures 6a, 6b, 6c, 6g and 6i), except in the soils with argillic horizons (pedons 1 and 2), where it can be speckled b-fabric when calcite depletion occurs (Table 4, Figure 6e). Within the studied soils coating and infilling of gypsum (as lenticular and psedo-hexagonal forms) and calcite crystals in voids and channels (Figure 5a) as well as Fe and Mn oxide nodules were common.

Few large lithogenic calcite nodules are impregnated by Fe oxides (Figure 6d). Calcite has been shown to be an efficient absorber of some impurities such as $\mathrm{Mn}^{2+}$, $\mathrm{Fe}^{2+}$, organic matter, etc (Van Beynen et al., 2001). Few $\mathrm{Fe} / \mathrm{Mn}$ oxides were observed as dense nodules in the matrix of non-aquic soils, due to less degree of weathering of primary minerals (Figures $6 \mathrm{~b}$ and $6 \mathrm{~d}$ ). In Bkg horizon of pedon 8 with an aquic condition, $\mathrm{Fe} / \mathrm{Mn}$ oxides were observed as distributed hypocoating around voids and channels (Figure 6f). In a micromorphological study in southwestern Iran, Owliaie (2014) reported two different distribution patterns of $\mathrm{Fe} / \mathrm{Mn}$ oxides in aquic and non-aquic soils due to more mobility of these oxides in aquic conditions. In aquic soils, these oxides were observed as hypocoating or quasicoating mostly with concentric internal fabric.

In the Btk horizon of pedon 1 located on a stable surface (plateau), some channels in thin sections, were covered with illuvial-clay coatings (Figure 6e)., however no clay coating was observed in the Btk horizon of pedon 2. More stability of pedon 1 compared to pedon 2 might be a reason for preserving clay skins. The absence of clay coating in thin sections of argillic horizons of highly calcareous soils of arid and semiarid regions is either tied to high shrink-swell potential, caused by the considerable amount of expandable clays (Nettleton et al., 1969; Nettleton and Peterson, 1983) or to the disruption force of growing crystals, such as gypsum or calcite (Khademi and Mermut, 2003) or to engulfment with carbonates (Mahmoodi, 1979). Soil horizons with high extensibility, were mostly missing clay coatings on the faces of peds because of high shrink-swell activity of the groundmass (Griffin and Buol, 1988). As mentioned above, smectite is the major clay mineral of the studied soils, particularly in more stable landforms.

SEM and thin section observations exhibited needle shaped (acicular) calcite as loose infilling in voids and channels of the Bk1 horizon of pedon 6 and Btk horizon of pedon 2 (Figure $5 \mathrm{c}$ and $6 \mathrm{c}$ ). The length and width range of these needles were 20 to $80 \mu \mathrm{m}$ and 1 to $2 \mu \mathrm{m}$, respectively. The origin of needle-shaped calcite has been discussed for a long time and is usually interpreted in two ways: in relation to organic material (roots, root hairs, bacteria, algae, and fungi) and as physicochemical phenomena (Wright, 1984).

Verrecchia and Verrecchia (1994) in a review on the morphology and genesis of needle-shaped calcite showed four types and several subtypes that from which three types are the result of biological methods whereas one is the result of physico-chemical crystallizations related to evaporation and desiccation. Preservation of needle-fiber calcite in soils indicates that the pedogenesis was weak (lack of leaching) and/or the climate of the environment was arid to semiarid (Wright, 1984). However, Strong et al. (1992) reported the occurrence of this form of calcite in cool and wet climate with abundant carbonate and high degree of biological activity.

Specific morphologies of calcite accumulation related to vegetation have been described in calcareous soils. In these soils, roots are responsible for the concentration of sparitic calcite crystals, also called cytomorphic 
calcite in the root channel (Jaillard et al., 1991). Cytomorphic calcites were observed in the Bk1 horizon of pedons 5 (Figure 5b). According to Monger (2002), biotic processes include $\mathrm{CO}_{2}$ input into the soil via respiration, $\mathrm{Ca}^{2+}$ extraction by roots, and direct precipitation by organisms. The results of a micromorphological study in the soils of Kohgilouye Province, southwestern Iran, showed that cytomorphic calcite pedofeature, was more common in the near-surface horizons of the regions with higher rainfall and denser vegetation (Owliaie, 2012).

Table 4. Thin section description of the pedons studied.

\begin{tabular}{|c|c|c|c|c|}
\hline $\begin{array}{l}\text { Pedon/ } \\
\text { horizon }\end{array}$ & Microstructure & $\begin{array}{l}\text { c/f ratio } \\
(10 \mu \mathrm{m})\end{array}$ & $\begin{array}{l}\text { Micromass, } \\
\text { b-fabric, color }\end{array}$ & Pedofeatures \\
\hline 1/Btk1 & $\begin{array}{l}\text { Moderate to well- developed } \\
\text { subangular blocky, partly } \\
\text { channel structure, porosity } \\
(\sim 15 \%)\end{array}$ & $4 / 6$ & $\begin{array}{l}\text { Crystallitic, } \\
\text { speckled b-fabric, } \\
\text { reddish brown }\end{array}$ & $\begin{array}{l}\text { Dense and loose calcite coating and } \\
\text { infilling in voids and channels, few to } \\
\text { common clay coatings, dark reddish to } \\
\text { black Fe/Mn oxides in matrix and Fe } \\
\text { impregnation in calcite nodules. }\end{array}$ \\
\hline 2/Btk & $\begin{array}{l}\text { Moderately developed } \\
\text { subangular blocky with } \\
\text { interpedal channels, porosity } \\
(\sim 20 \%)\end{array}$ & $3 / 7$ & $\begin{array}{l}\text { Crystallitic, } \\
\text { speckled b-fabric, } \\
\text { reddish brown }\end{array}$ & $\begin{array}{l}\text { Coating of calcite in channels and voids, } \\
\text { small calcite nodules, dark reddish to } \\
\text { black Fe/Mn oxides in matrix. }\end{array}$ \\
\hline 2/Bk1 & $\begin{array}{l}\text { Weak developed } \\
\text { subangular blocky, partly } \\
\text { channel structure, porosity } \\
(\sim 10 \%)\end{array}$ & $5 / 5$ & $\begin{array}{l}\text { Crystallitic, b- } \\
\text { fabric, ellowish } \\
\text { brown }\end{array}$ & $\begin{array}{l}\text { Loose and dense calcite infilling in voids } \\
\text { and channels, coating of calcite along } \\
\text { channels, few micritic calcite nodules, few } \\
\text { Fe-Mn oxide in ground mass }\end{array}$ \\
\hline 4/Bw & $\begin{array}{l}\text { Moderately developed } \\
\text { subangular blocky, porosity } \\
(\sim 50 \%)\end{array}$ & $4 / 6$ & $\begin{array}{l}\text { Crystallitic b- } \\
\text { fabric, light } \\
\text { yellowish brown }\end{array}$ & $\begin{array}{l}\text { Few micritic calcite nodules, few Fe-Mn } \\
\text { oxide in ground mass }\end{array}$ \\
\hline 4/Bky2 & $\begin{array}{l}\text { Weak developed subangular } \\
\text { blocky, porosity }(\sim 30 \%)\end{array}$ & $6 / 4$ & $\begin{array}{l}\text { Crystallitic b- } \\
\text { fabric, light } \\
\text { yellowish brown }\end{array}$ & $\begin{array}{l}\text { Coating of calcite in channels, few medium } \\
\text { to large lenticular gypsum crystals in } \\
\text { voids, channels and matrix. }\end{array}$ \\
\hline 5/Bky & $\begin{array}{l}\text { Weak developed subangular } \\
\text { blocky porosity }(\sim 20 \%) \text { with } \\
\text { some planes }\end{array}$ & $3 / 7$ & $\begin{array}{l}\text { Crystallitic b- } \\
\text { fabric, light brown }\end{array}$ & $\begin{array}{l}\text { Infilling of calcite in channels and voids, } \\
\text { few fine to medium gypsum crystals in } \\
\text { voids and matrix }\end{array}$ \\
\hline 6/Bk1 & $\begin{array}{l}\text { Moderately developed } \\
\text { subangular blocky with } \\
\text { interpedal channels, porosity } \\
(\sim 20 \%)\end{array}$ & $3 / 7$ & $\begin{array}{l}\text { Crystallitic b- } \\
\text { fabric, yellowish } \\
\text { brown }\end{array}$ & $\begin{array}{l}\text { Dense calcite infilling in voids and } \\
\text { channels, few needle-like calcite crystals, } \\
\text { few Fe-Mn oxide in ground mass }\end{array}$ \\
\hline 7/Bw1 & $\begin{array}{l}\text { Weak to moderately developed } \\
\text { subangular blocky with some } \\
\text { planes, porosity }(\sim 20 \%)\end{array}$ & $4 / 6$ & $\begin{array}{l}\text { Crystallitic b- } \\
\text { fabric, yellowish } \\
\text { brown }\end{array}$ & $\begin{array}{l}\text { Few micritic calcite nodules, few Fe-Mn } \\
\text { oxide in ground mass and calcite nodules. }\end{array}$ \\
\hline 8/Apg & $\begin{array}{l}\text { Weak developed subangular, } \\
\text { porosity }(\sim 25 \%)\end{array}$ & $4 / 6$ & $\begin{array}{l}\text { Crystallitic b- } \\
\text { fabric, yellowish } \\
\text { red }\end{array}$ & $\begin{array}{l}\text { Very few calcite nodule, oxidized plant } \\
\text { residues, Fe-Mn oxide in ground mass }\end{array}$ \\
\hline 8/Bkg & $\begin{array}{l}\text { Weak developed subangular, } \\
\text { porosity }(\sim 25 \%)\end{array}$ & $2 / 8$ & $\begin{array}{l}\text { Crystallitic b- } \\
\text { fabric, reddish } \\
\text { brown }\end{array}$ & $\begin{array}{l}\text { Few calcite nodule, calcite infilling in voids } \\
\text { and channels oxidized, plant residues, } \\
\text { hypocoating of Fe oxide in voids }\end{array}$ \\
\hline 9/Ap & $\begin{array}{l}\text { Weak developed subangular, } \\
\text { porosity }(\sim 20 \%)\end{array}$ & $3 / 7$ & $\begin{array}{l}\text { Crystallitic b- } \\
\text { fabric, yellowish } \\
\text { brown }\end{array}$ & $\begin{array}{l}\text { Very few calcite nodule, oxidized plant } \\
\text { residues, spheroidal faunal excrements in } \\
\text { voids and channels }\end{array}$ \\
\hline
\end{tabular}

Faunal excrements were observed in thin section of Ap horizon of pedon 8. These pedofeatures were as organic spheroids (less than $25 \mu \mathrm{m}$ in diameter), and as a vermiform structure with oriented fabric (50 to $150 \mu \mathrm{m}$ in length), within voids and channels, suggesting high biological activity in this soil (Figure 6j). In addition, plant residues (organs and tissues) in different stages of decomposition, were observed in the thin sections of some surface soils (Figures $6 \mathrm{~h}$ and $6 \mathrm{j}$ ). Lenticular, sub-lenticular and pseudo-hexagonal gypsum crystals, are dominant pedofeatures observed in the thin sections of the Bky1 and Bky2 horizons of pedon 4 (Figure 6g) and Bky horizon of pedon 5 (Figures 6i). Gypsum interlocked plates were found mostly in deeper horizons with a larger content of gypsum. SEM observations showed gypsum crystals as individual prismatic crystals (80 to $100 \mu \mathrm{m}$ in length and $20 \mu \mathrm{m}$ in width) distributed in soil matrix (Figure 5e), and subhedral crystals $(20$ to $30 \mu \mathrm{m}$ ) located in large voids (Figure 5f). The lenticular crystals vary in length between 100 and $250 \mu \mathrm{m}$ and in diameter between 50 and $100 \mu \mathrm{m}$. Larger crystals were found in the soils with larger voids. Jafarzadeh and Burnham (1992) believed that lenticular gypsum crystals may form in any environmental condition. However, Amit and Yaalon (1996) have reported ionic impurity and unlimited pore space as the necessary conditions for the formation of lenticular gypsum. 

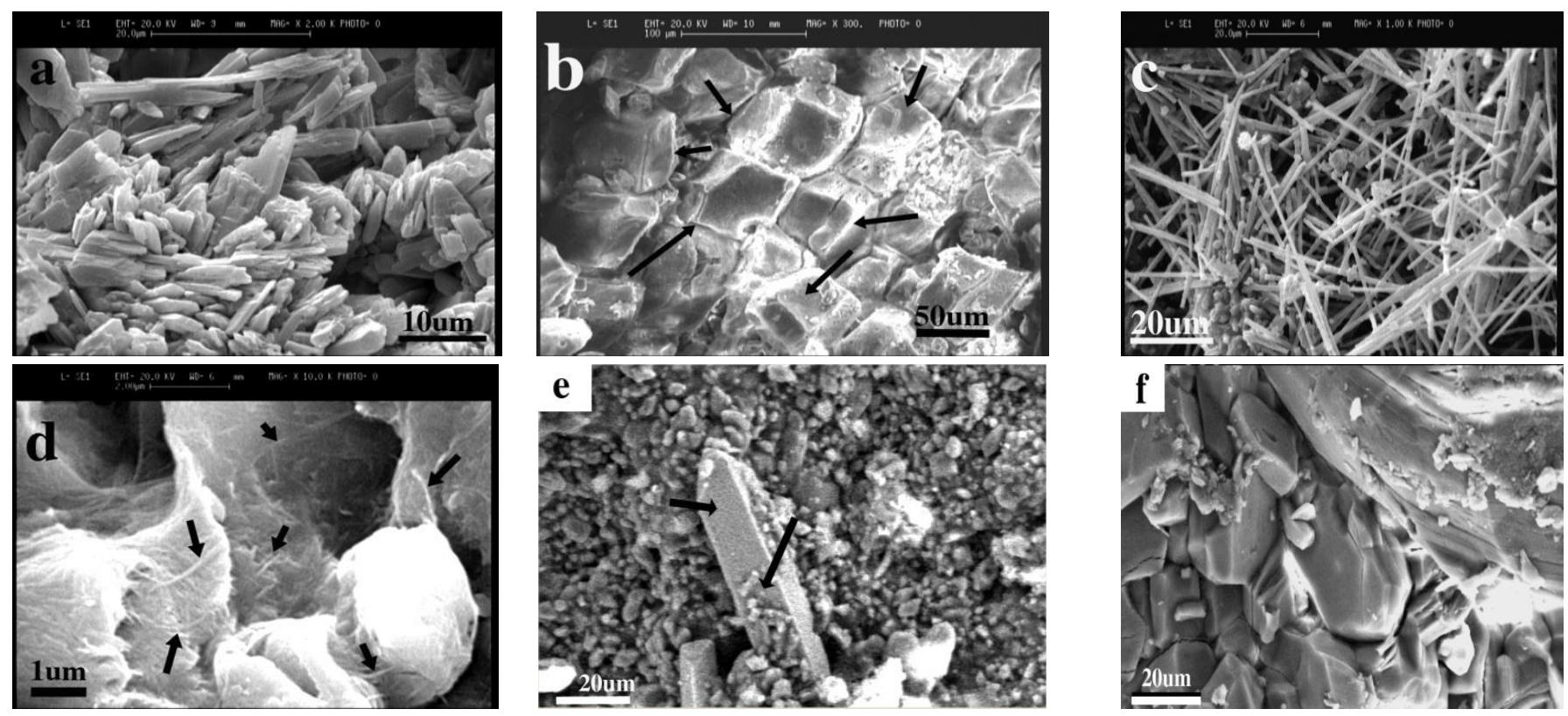

Figure 5. SEM micrographs of (a) euhedral calcite crystal of Bk2 horizon of pedon 6, (b) cytomorphic calcite crystals, Bk1 horizon of pedon 2 (c) needle-like calcite crystals of Btk horizon of pedon 2, (d) palygorskite fibers on gypsum crystal, Bky1 horizon of pedon 4, (e) individual prismatic gypsum crystal, Bky1 horizon of pedon 4, (f) integration of subhedral gypsum crystals, Bky horizon of pedon 5 .
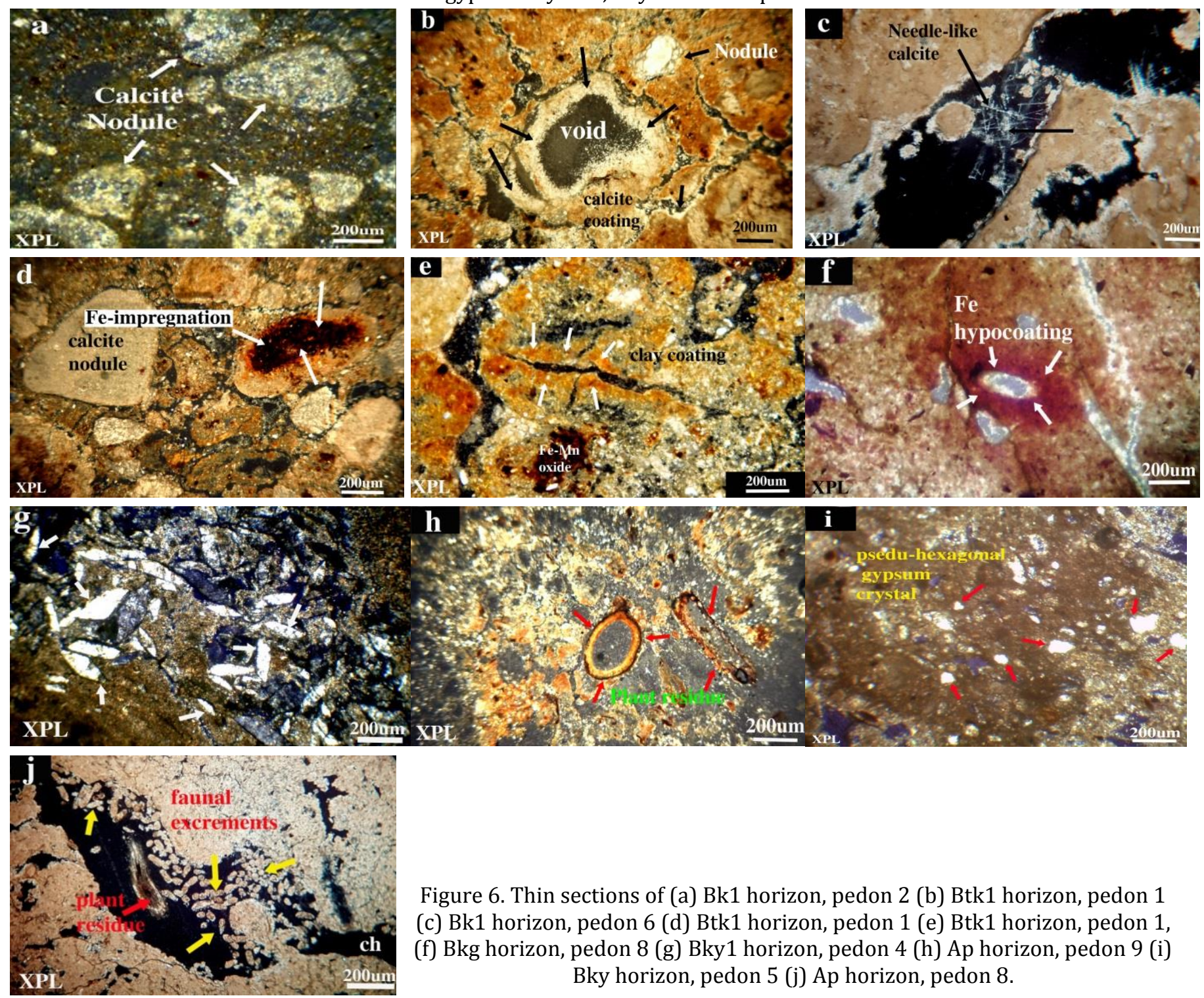

Figure 6. Thin sections of (a) Bk1 horizon, pedon 2 (b) Btk1 horizon, pedon 1

(c) Bk1 horizon, pedon 6 (d) Btk1 horizon, pedon 1 (e) Btk1 horizon, pedon 1,

(f) Bkg horizon, pedon 8 (g) Bky1 horizon, pedon 4 (h) Ap horizon, pedon 9 (i) Bky horizon, pedon 5 (j) Ap horizon, pedon 8. 


\section{Conclusion}

The results of the present study showed that soil formation on different physiographic surfaces and geological strata and its physicochemical, mineralogical, and micromorphological characteristics are closely influenced by landscape position and parent material. More developed soils were found on the stable plateau and piedmont plain; however, the soils formed on the unstable river alluvial plain and alluvial fan showed a minimum of development. Spatial distribution of calcareous and gypsiferous geological strata was responsible for the occurrence of calcic and gypsic horizons in the studied pedons. Mountain runoff water is the main source for the soil gypsum. The depth of calcic and gypsic horizons in the soils was highly related to the amount of precipitation and landscape position. The presence of argillic horizons in the more stable positions of plateau and piedmont plain soils in a semi-arid region indicated a more humid paleoclimate in the history of the area. Smectite, illite, chlorite, palygorskite, kaolinite and quartz clay minerals were identified in almost all landscape surfaces, but more palygorskite and less smectite were found in the soils with gypsiferous parent materials. A large amount of smectite is inherited from the marl formations, although some may be the product of transformation of illite and also palygorskite weathering, particularly at the surface horizons. In the soil with aquic soil moisture regime, neoformation of smectite seems to be the main pathway for the occurrence of this clay mineral. Coating and infilling of gypsum and calcite crystals in voids and channels as well as Fe and Mn oxide nodules and hypocoating (in aquic soil) were common pedofeatures observed in the soils studied. Faunal excrements were observed in the thin section of surface horizons with more biological activity. Co-occurrence of illuvial clay features and pedogenic carbonates were observed in pedons located on the stable physiographic surface suggesting the occurrence of polygenetic soils.

\section{References}

Abbaslou, H., Abtahi, A., Martin Peinado, F.J., Owliaie, H. Khormali, F., 2013. Mineralogy and characteristics of soils developed on Persian Gulf and Oman sea basin, southern Iran: implications for soil evolution in relation to sedimentary parent material. Soil Science 178 (10): 568-584.

Abtahi, A., 1980. Soil genesis as affected by topography and time in calcareous parent materials. Soil Science Society of America Journal 44(2): 329-336.

Abtahi, A., Khormali, F., 2001. Genesis and morphological characteristics of Mollisols formed in a catena under water table influence in southern Iran. Communications in Soil Science and Plant Analysis 32(9-10): 1643-1658.

Amit, R., Yaalon, A.D., 1996. The micromorphology of gypsum and halite in Reg soils: the Negev desert, Israel. Earth Surface Processes and Landforms 21(12): 1127-1143.

Aoudjit, M., Robert, M., Elsass, F., Curmi, P., 1995. Detailed study of smectite genesis in granitic saprolites by analytical electron microscopy. Clay Minerals 30(2): 135 -147.

Badraoui, M., Bloom, P.L., Bouabid, R., 1992. Palygorskite-Smectite association in a xerochrept of the high Chaouia Region of Morocco. Soil Science Society of America Journal 56(5): 1640-1646.

Banaei, M.H., 1998. Soil moisture and temperature regime map of Iran. Soil and Water Research Institute. Ministry of Agriculture, Tehran, Iran.

Birkeland, P.W., 1999. Soils and Geomorphology. $3^{\text {rd }}$ Edition. Oxford University Press, New York, USA. 430p.

Boettinger, J.L., Southard, R. J., 1995. Phyllosilicate distribution and origin in aridisols on a granitic pediment, Western Mojave desert. Soil Science Society of America Journal 59(4): 1189-1198.

Branhisel, R.L., Berstesch, P.M., 1992. Cholorites and hydroxy interlayer vermiculite and smectite. In: Minerals in soil environments. Dixon, J.B., Weeds, S.B. (Eds.). Soil Science Society of America, Book Series No. 1, Soil Science Society of America, Madison, WI, USA. pp. 729-788.

Buck, B.J., Van Hoesen, J.G., 2002. Snowball morphology and SEM analysis of pedogenic gypsum, southern New Mexico, U.S.A. Journal of Arid Environments 51(4): 469-487.

Carter, B.J., Inskeep, W.P., 1988. Accumulation of pedogenic gypsum in western Oklahoma soils. Soil Science Society of America Journal 52(4): 1107-1113.

Chapman, H.D., 1965. Cation exchange capacity. In: Methods of Soil Analysis. Part II, Black, C.A. (Ed.). Agronomy No. 9. American Society of Agronomy, Madison, Wisconsin, USA. pp. 891-901.

Churchman, G.J., Lowe, D.J., 2012. Alteration, formation, and occurrence of minerals in soils. In: Handbook of Soil Sciences: Properties and Processes. Huang, P.M., Li, Y., Sumner, M.E., CRC Press, Boca Raton, FL, USA. pp. 1-72.

Dahlgren, R.H., Boettinger, J.L., Huntington, G.L., Amundson, R.G., 1997. Soil development along an elevational transect in the western Sierra Nevada, California. Geoderma 78(3-4): 207-236.

Day, P.R., 1965. Particle fractionation and particle-size analysis. In: Methods of Soil Analysis. Part I, Black, C.A. (Ed.). Agronomy No. 9. American Society of Agronomy, Madison, Wisconsin, USA. pp. p. 545- 566.

Dixon, J.B., Skinner, H.C.W., 1992. Manganese minerals in surface environments. In: Biomineralization processes of iron and manganese: modern and ancient environments. Skinner, H.C.W., Fitzpatrick, R.W., (Eds.), CremlingenDestedt: Catena Verlag. pp. 31-50. 
Dixon, J.B., Weed, S.B., 1989. Minerals in soil environments. $2^{\text {nd }}$ ed. Soil Science Society of America, Book Series No. 1, Soil Science Society of America, Madison, WI, USA. 1244 p.

FA0, 2015. World Reference Base for Soil Resources 2014. International soil classification system for naming soils and creating legends for soil maps. World Soil Resources Reports No. 106. Food and Agriculture Organization of the United Nations (FAO), Rome, Italy. Available at: [access date: 02.10.2017]: http://www.fao.org/3/a-i3794e.pdf

Farpoor, M.H., Khademi, H., Eghbal, M.K. 2002. Genesis and distribution of palygorskite and associated clay minerals in Rafsanjan soils on different geomorphic surfaces. Iran Agricultural Research 21(1): 39-60.

Geological Survey of Iran, 1995. Geological Quadrangle Map. No. 111, Geology Organization of Iran.

Gerrard, J., 1992. Soil Geomorphology. Chapman and Hall Pub. Company, London. 269 p.

Gharaee, H.A., Mahjoory, R.A., 1984. Characteristics and geomorphic relationships of some representative Aridisols in southern Iran. Soil Science Society of America Journal 48(5): 1115- 1119.

Gillot, F., Righi, D., Elsass, F., 2000. Pedogenic smectites in podzols from central Finland: an analytical electron microscopy study. Clays and Clay Minererals 48(6): 665-664.

Griffin, R.W., Buol, S.W., 1988. Soil and saprolite characteristics of vertic and aquic Hapludults derived from Triassic Basin sandstones. Soil Science Society of America Journal 52(4): 1094-1099.

Hashemi, S.S., Baghernejad, M., Khademi, H., 2011. Micromorphology of gypsum crystals in southern Iranian soils under different moisture regimes. Journal of Agricultural Science and Technology 13(2): 273-288.

Jackson, M.L., 1975. Soil Chemical Analysis. Advanced Course Univ. of Wisconsin, College of Agric., Dept. of Soils, Madison, WI. 894 pp.

Jafarzadeh, A.A., Burnham, C.P., 1992. Gypsum crystals in soils. European Journal of Soil Science 43(3): 409-420.

Jaillard, B., Guyon, A., Maurin, A.F., 1991. Structure and composition of calcified roots, and their identification in calcareous soils. Geoderma 50(3): 197-210.

Johns, W.D., Grim, R.E., Bradley, F., 1954. Quantitative estimation of clay minerals by diffraction methods. Journal of Sedimentary Petrology 24(4): 242-251.

Khademi, H., Mermut, A.R., 2003. Micromorphology and classification of Argids and associated gypsiferous Aridisols from central Iran. Catena 54(3): 439-455.

Khormali, F., Abtahi, A., 2003. Origin and distribution of clay minerals in calcareous arid and semi-arid soils of Fars Province. Clay Minerals 38(4): 511-527.

Khormeli, F., Abtahi, A., Stoops, G., 2006. Micromorphology of calcitic features in highly calcareous soils of Fars Province, Southern Iran. Catena 132(1-2): 31-46.

Khresat, S.A., Qudah, E.A., 2006. Formation and properties of aridic soils of Azraq Basin in northeastern Jordan. Journal of Arid Environments 64(1): 116-136.

Kittrick, J.A., Hope, E.W., 1963. A procedure for the particle size separation of soils for X-ray diffraction analysis. Soil Science 96(5): 319-325.

Lark, R.M., 1999. Soil-landform relationships at within-field scales: an investigation using continuous classification. Geoderma 92(3-4): 141-165.

Liu, F., Colombo, C., Adamo, P., He, J.Z., Violante, A., 2002. Trace elements in manganese-iron nodules from a Chinese Alfisol. Soil Science Society of America Journal 66(2): 661-670.

Mahjoory, R.A., 1975. Clay mineralogy, physical and chemical properties of some soils in arid regions of Iran. Soil Science Society of America Journal 39(6): 1157-1164.

Mahmoodi, Sh. 1979. Genesis and characterization of some soils from the Karaj Basin Iran [Ph.D. thesis]. Ghent University, Ghent, Belgium.

McBratney, A.B., Odeh, I.O.A., Bishop, T.F.A., Dunbar, M.S. Shatar, T.M., 2000. An overview of pedometric techniques for use in soil survey. Geoderma 97(3-4): 293-327.

McKenzie, RM., 1989. Manganese oxides and hydroxides. In: Minerals in soil environments. Dixon, J.B., Weeds, S.B. (Eds.). Soil Science Society of America, Book Series No. 1, Soil Science Society of America, Madison, WI, USA. pp. 439-465.

Moazallahi, M., Farpoor, M.H., 2009 Soil micromorphology and genesis along a lithotoposequence in Kerman Province, central Iran. Australian Journal of Basic and Applied Sciences 3(4): 4078-4084.

Moazallahi, M., Farpoor, M.H., 2011. Soil genesis and clay mineralogy along the xeric-aridic climotoposequence, south central Iran. Journal of Agricultural Science and Technology 14(3): 683-696.

Monger, H.C., 2002. Pedogenic carbonate: links between biotic and abiotic CaCO3. Proceedings of $17^{\text {th }}$ World Conference of Soil Science, Paper No 897. 14-21 August 2002, Bangkok, Thailand.

Monger, H.C., Daugherty, L.A., 1991. Neoformation of palygorskite in a southern New Mexico Aridisol. Soil Science Society of America Journal 55(6):1646-1650.

Moore, D.M., Reynolds, R.C.J., 1997. X-Ray diffraction and the identification and analysis of clay minerals. Oxford University Press, USA. 400p.

Murphy, C.P., 1986. Thin section preparation of soils and sediments. AB Academic. Berkhamsted, USA. 149p.

Nadimi, M, Farpoor, M.H., 2013. Genesis and clay mineralogy of soils on different geomorphic surfaces in Mahan-Joupar area, central Iran. Arabian Journal of Geosciences 6(3): 825-833. 
Nettleton, W.D., Flash, K.W., Brasher, B.R., 1969. Argillic horizons without clay skins. Soil Science Society of America Journal 33(1): 121-125.

Nettleton, W.D., Peterson, F.F., 1983. Aridisols. In: Pedogenesis and soil taxonomy: II. The soil orders. Wilding, L.P., Smeck, N.E., Hall, G.F., (Eds.), Elsevier, Amsterdam, The Netherlands, pp.165-215.

Nooraie, K., 2010. Soil genesis and classification in Sirch-Kaleshoor toposequence, Loot watershed, Kerman. M.Sc. thesis, Kerman University, Iran, 127 pp [in Persian].

Owliaie, H.R., 2012. Micromorphology of Pedogenic Carbonate Features in Soils of Kohgilouye, Southwestern Iran. Journal of Agricultural Science and Technology 14(1): 225-239.

Owliaie, H.R., 2014. Soil genesis along a Catena in Southwestern Iran: A micromorphological approach. Archives of Agronomy and Soil Science 60(4): 471-486.

Owliaie, H.R., Abtahi, A., Heck, R.J. 2006. Pedogenesis and clay mineralogical investigation of soils formed on gypsiferous and calcareous materials, on a transect, Southwestern Iran. Geoderma 134(1-2): 62-81.

Pletsch, T., Daoudi, L., Chamley, H., Deconinck, J.F., Charroud, M., 1996. Palaeogeographic controls on palygorskite occurrence in mid-Cretaceous sediments of Morocco and adjacent basins. Clay Minerals 31(3): 403-416.

Rezapour, S., 2014. Response of some soil attributes to different land use types in calcareous soils with Mediterranean type climate in north-west of Iran. Environmental Earth Science 71(5): 2199- 2210.

Rezapour, S., Samadi, A., Khodaverdiloo, H., 2012. Impact of long-term wastewater irrigation on variability of soil attributes along a landscape in semi-arid region of Iran. Environmental Earth Science 67(6): 1731-1723.

Salehi, M.H., Khademi, H., Eghbal, M.K., 2002. Genesis of clay minerals in soils from Chaharmehal Bakhtiari Province, Iran. Conference on Sustainable Use and Management of Soils in Arid and Semiarid Region. September 2002. Cartagena, Spain. Book of Abstracts. pp. 47-48.

Salinity Laboratory Staff, 1954. Diagnosis and improvement of saline and alkali soils. United States Department of Agriculture, Agriculture Handbook No. 60. Washington DC, USA. 160p.

Sangüesa, F.J., Arostegui, J., Suarez-Ruiz, I., 2000. Distribution and origin of clay minerals in the Lower Cretaceous of the Alava Block (Basque-Cantabrian Basin, Spain). Clay Minerals 35(2): 393-410.

Sanjari, S., Farpoor, M.H., Eghbal, M.K., Boroujeni, E.I., 2011. Genesis, micromorphology and clay mineralogy of soils located on different geomorphic surfaces in Jiroft area. Journal of Water and Soil 25(2): 411-425 [In Persian].

Sarmast, M., Farpoor, M.H., Boroujeni, E.I., 2016. Comparing Soil Taxonomy (2014) and updated WRB (2015) for describing calcareous and gypsiferous soils, Central Iran. Catena 145: 85-91.

Sarmast, M., Farpoor, M.H., Boroujeni, E.I., 2017. Soil and desert varnish development as indicators of landform evolution in central Iranian deserts. Catena 149(1): 98-109.

Schaetzl, R., Anderson, S., 2005. Soils: genesis and geomorphology. Cambridge University Press. New York, USA. 656p.

Singer A., 1989. Palygorskite and sepiolite group minerals. In: Minerals in soil environments. Dixon, J.B., Weeds, S.B. (Eds.). Soil Science Society of America, Book Series No. 1, Soil Science Society of America, Madison, WI, USA. pp. 829- 872.

Singer, A., 1984. Clay formation in saprolites of igneous rocks under semi-arid to arid conditions, Negev, Southern Israel. Soil Science 137: 332-340.

Soil Survey Staff, 2014. Keys to soil taxonomy. 12 ${ }^{\text {th }}$ Edition. U.S. Department of Agriculture, Natural Resources Conservation Service. Washington DC, USA.

Stoops, G., 2003. Guidelines for the analysis and description of soil and regolith thin sections. Soil Science Society of America. Madison, WI, USA. 184p.

Stoops, G., Delvigne, J., 1990. Morphology of mineral weathering and neoformation. II. Neoformations. In: Soil micromorphology: a basic and applied science, developments in soil science. Douglas, L.A., (Ed.). Elsevier, Amsterdam, The Netherlands, pp.329-350.

Strong, G.E., Giles, J.R.A., Wright, V.P., 1992. A Holocene calcrete from North Yorkshire, England: implications for interpreting palaeoclimates using calcretes. Sedimentology 39(2): 333-347.

van Beynen, P., Bourbonniere, R., Ford, D. Schwarez, H. 2001. Causes of colour and fluorescence in speleothems. Chemical Geology 175(3-4): 319-341.

Verrecchia, E.P., Verrecchia, K.E., 1994. Needle-fiber calcite: a critical review and a proposed classification. Journal of Sedimentary Research 64(3a): 650-664.

Wilson, M.J., 1999. The origin and formation of clay minerals in soils: past, present and future perspectives. Clay Minerals 34(1): 7-25.

Wright, V.P., 1984. The significance of needle-fibre calcite in a Lower Carboniferous palaeosol. Geology Journal 19(1): 23-32.

Wright, V.P., 1987. A Micromorphological Classification of Fossile and Recent Calcic and Petrocalcic Microstructures. In: Soil Micromorphology, Fedoroff, N., Bresson, L.M., Courty, M.A., (Eds.), AFES, Paris, France. pp.401-407.

Zhang, M., Karathanasis, A.D., 1997. Characterization of iron-manganese concretions in Kentucky Alfisols with perched water tables. Clays and Clay Minerals 45(3): 428-439. 